Г. Л. Черюкина

Ростов-на-Дону

DOI: 10.15393/j9.art.2011.309

\section{ЛИТЕРАТУРНЫЕ ВЕРСИИ \\ ПРИТЧИ О БЛУДНОМ СЫНЕ В РОМАНАХ «НЕКУДА» Н. С. ЛЕСКОВА И «ОБРЫВ» И. А. ГОНЧАРОВА}

В русской классической литературе одним из самых распространенных и устойчивых является архетип блудного сына. Этот евангельский мотив лежит в сюжетной основе произведений многих писателей и служит образованию тематического ряда, в свою очередь порождающего яркие образы героев, генетически связанных именно с этим архетипом. В процессе работы с различными художественными текстами фрормируется устойчивое ощущение, что именно в русской литературе получает распространение воплощение этого архетипа не в мужских, а в женских персонажах.

В современном отечественном литературоведении этот феномен неоднократно подвергался тщательному анали-

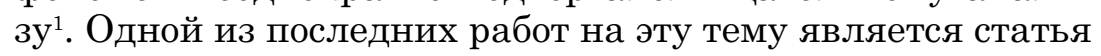

\footnotetext{
(c) Черюкина Г. Л., 2011

${ }^{1}$ См.: Гольденберг A. X. Притча о блудном сыне в «Мертвых душах» и древнерусская литературная традиция // Литературное произведение и литературный процесс в аспекте исторической поэтики. Кемерово, 1988; Он же. «Вечный» сюжет у Гоголя и кризисные модели русской литературы // Гоголевский сборник. СПб.; Самара, 2003; Мелетинский E. M. Историческая поэтика новеллы. М., 1990. С. 231; Тюпа В. И. Притча о блудном сыне в контексте «Повестей Белкина» как художественного целого // Болдинские чтения. Горький, 1983; Он же. Мотив в системе художественного целого // Силантьев И. В., Тюпа В. И., Шатин Ю. В.
}

Е. А. Суркова, в которой автор обращается к проблеме воплощения популярного библейского сюжета в «Станционном смотрителе» А. С. Пушкина. Прослеживая историю трансформации евангельской притчи в русской литературе с «Комедии притчи о блудном сыне» Семиона Полоцкого до произведений сентименталистов, исследователь высказывает следующее суждение:

В русской традиции притча о блудном сыне окружена своими «опрощенными» литературными моделями, которые имели, по всей видимости, важное смыслообразующее и текстопорождающее значение... ${ }^{2}$

Здесь же Е. А. Сурков форомулирует еще один тезис, интересующий нас в рамках обозначенной проблемы:

...Возникающий в связи с притчей резонный вопрос о том, как сюжет о блудном сыне превратился в рассказ о блудной дочери, так и остался пока неразрешенным. Принято констатировать в этом случае только то, что в повести Пушкина притча о блудном сыне «переиначивается», «нарушается» или «дестабилизируется». <..> Однако, если мы говорим о коммуникативных стратегиях культуры и об общем дискурсивном ее пространстве, мы должны определить потенциальные или наличествующие, но реальные возможности такого превращения. В русской традиции должен был существовать прецедент семантической трансформации сюжета или мотива... ${ }^{3}$

Автор статьи достаточно убедительно доказывает, что в истории русской литературы не просто создается прецедент такого "переиначивания», а складывается традиция воспроизведения вечного сюжета именно в женских обpaзах.

Продолжая разговор об укреплении данной тенденции, хотелось бы внести ряд дополнительных обоснований про-

Мотивный анализ. Новосибирск, 2004. С. 176; Хлызова И. Ю. Жанровая дестабилизация притчи о блудном сыне в древнерусских бытовых повестях // Мировая культура XVII-XVIII веков как метатекст: дискурсы, жанры, стили. СПб., 2002.

${ }^{2}$ Сурков E. A. Притча о блудном сыне и «рассказ» о блудной дочери // Русская словесность: проблемы эволюции и поэтики: Сб. науч. ст. СПб., 2008. С. 33.

${ }^{3}$ Там же. С. 39 
блемы возникновения литературных версий, генетически связанных с библейской притчей о блудном сыне.

Обращает на себя внимание тот фракт, что замена «сына» образом «дочери» характерна в большей мере для писателей, в творчестве которых женские персонажи относительно самостоятельны и интересуют автора прежде всего как яркие автономные типы. В ряду наиболее значительных художников слова XIX века в этом отношении выделяются Н. С. Лесков и И. А. Гончаров. С точки зрения заявленной проблемы наиболее показательными являются образы Лизы Бахаревой, героини романа «Некуда», и Веры из романа «Обрыв». Именно с ними связаны не только основные сюжетные линии этих произведений, но и четкая идейная направленность, обусловленная авторским идеалом.

Типологическая связь этих двух героинь обозначена на многих уровнях. Это и их помещенность в определенный исторический контекст, и знаковость их образов в понимании культурной парадигмы, связанной с сугубо национальной традицией, и взаимосвязи с другими персонажами романов. Психологические портреты Лизы и Веры сближают эти образы и позволяют говорить об определенном женском типе, формиирующемся на конкретном этапе общественного развития. При этом остается очевидным, что судьбы этих девушек складываются по-разному в силу не только внешних обстоятельств, но и личностного сознания, определяющего их поступки. Важной составляющей в событийном плане романов остается антинигилистическая тенденция, связанная с приоритетом сохранения родового начала как залога благополучия исторического процесса, что в полной мере соответствует авторской аксиологии.

Но прежде чем перейти к рассмотрению типологических особенностей заявленных образов-персонажей, не будет лишним обратиться к более традиционной интерпретации библейской притчи в романистике 60 -х годов XIX века. Хотелось бы заострить внимание на еще одной яркой литературной иллюстрации в воплощении этого сюжета в рамках складывающейся традиции в русской классике. Речь пойдет о судьбе Наташи Ихменевой в романе Ф. М. Достоевского «Униженные и оскорбленные». На тесную связь әтого произведения с евангельским сюжетом, а также на литературный генезис в рамках обозначенной проблемы указывает В. И. Габдуллина. Подробно рассматривая притчевую основу романа и причины преображения притчи о блудном сыне в рассказ о блудной дочери, исследовательница приходит к выводу:

Очевидно, что параллельное изображение двух историй, ориентированных на библейский сюжет и имеющих различные финалы, имело для автора принципиальное значение. Представив историю двух семейств - семьи англичанина Смита и русской семьи Ихменевых, Достоевский столкнул в романе две нравственные позиции, изобразил два варианта решения одного вопроса: в духе европейского индивидуализма и «по народной вере и правде» ${ }^{4}$.

Вывод этот вполне убедителен, но хотелось внести некоторые дополнения относительно наличия двух сюжетных линий именно в связи с обозначенной проблемой.

С уверенностью можно сказать, что Достоевский сознательно усложняет сюжетный ход и расщепляет его на две параллельные линии, в одной из которых евангельская притча не получает своего завершения. Несмотря на то что образ Нелли является центральным, как основной сюжет следует воспринимать историю семьи Ихменевых. История же внутрисемейных взаимоотношений Смитов является альтернативной иллюстрацией и выполняет вспомогательную сюжетную функцию. Жизненная драма матери Нелли приводит к трагическому фриналу, но не по вине самой беглянки, а по вине ее отца, старика Смита, запоздалого прощения которого так и не дождалась его умирающая дочь. Другое дело - судьба Наташи, покинувшей отчий дом. Оказавшись в безвыходном положении, она возвращается и получает со стороны отца полное прощение, видит его искреннюю радость по поводу ее возвращения. Параллелизм судеб двух героинь в романе становится необходимым приемом для подтверждения вечных законов бытия, в реализации одного из самых известных и востре-

${ }^{4}$ Габдуллина В. И. «Блудные дети, двести лет не бывшие дома»: евангельская притча в авторском дискурсе Ф. М. Достоевского. Барнаул, 2008. C. 153 . 
бованных в рамках литературной интерпретации библейских сюжетов. Запоздалое и неполученное при жизни прощение отца в истории жизни матери Нелли имеет свою назидательную цель и становится основным катализатором в действиях старика Ихменева, спешащего простить свою раскаявшуюся дочь.

Основными в реализации сюжета притчи о блудном сыне становятся четыре мотива: отпадения, беспомощности, возвращения, прощения. В рассматриваемых произведениях эти мотивы комплектуются неравнозначно, а следовательно, и сами сюжеты, генетически связанные с одной и той же притчей, получают разное звучание. Если у Достоевского все четыре мотива реализуются сполна и можно говорить о благополучном завершении сюжета, то ни у Лескова, ни у Гончарова мы не обнаружим полного комплекта, необходимого для счастливого финала, причем выпадают разные мотивы. У Достоевского в случае с матерью Нелли исчезает мотив прощения (хотя Смит, как мы помним, прощает свою дочь, но слишком поздно), у Лескова в случае с Лизой - мотив возвращения, а в случае с Верой - мотив отпадения. Но тогда возникает вопрос, почему же ситуация, в которой оказывается Вера, не воспринимается как история со счастливым концом. Дело в том, что, когда речь заходит об основополагающих мотивах, в первую очередь мы имеем в виду собственно сюжет, и на уровне сюжетного повествования отсутствие первого мотива очевидно. Однако именно в отношениях Веры с другими персонажами обнаруживается любопытное явление: не отрицая родовых ценностей, она пытается «жить своим умом».

Налицо психологическая эмансипация героини, приводящая к утрате твердой почвы, защиты и, как закономерному следствию, беспомощности Веры, ее неспособности самостоятельно справиться с критической жизненной ситуацией. Кроме того, отсутствие благополучного завершения сюжета романа не означает отсутствия положительной перспективы, и в этом отношении можно говорить об определенной сюжетной незавершенности. В случаях же матери Нелли в «Униженных и оскобленных» и Лизы Бахаревой в романе «Некуда» смерть героинь ставит точку в их судьбах, трагизм которых обусловлен их отречением от отчего дома и невозвращением в него. Но и здесь мы сталкиваемся с разнопричинностью этого невозвращения. В первом случае автор обвиняет не саму героиню, а ее отца, не принявшего свою блудную дочь и не успевшего вовремя дать ей свое прощение. Лиза же вполне сознательно отказывается от возвращения и, соответственно, от прощения, которое, безусловно, было бы дано ей семьей. Показательна сцена смерти героини, в которой она категорически отказывается от исповеди и покаяния:

Все существо старухи обратилось с этой минуты в живую заботу о том, чтобы больная исповедовалась и причастилась.

- Матушка, Лизушка, - говорила она, заливаясь слезами, - ведь от этого тебе хуже не будет. Ты ведь христианского отца с матерью дитя: пожалей ты свою душеньку.

- Оставьте меня, - говорила, отворачиваясь, Лиза 5 .

Отказ Лизы Бахаревой от родовых связей ведет к полному отказу от вечных ценностей и абсолютному выпадению героини из культурно-исторического контекста, принадлежность к которому стала бы защитой и опорой в сложной жизненной ситуации, обусловленной не только ее личностным сознанием, но и социально-историческими явлениями эпохи. Однако влияние общественных явлений и тенденций на сознание Лизы не оправдывает саму героиню и не снимает с нее личной ответственности за сделанный выбор. Ведь в тех же условиях находится и Женни Гловацкая, но именно ее образ предлагается автором как положительный. Кстати, и в ее жизни обнаруживаются формальные составляющие библейской притчи, но она, в отличие от Лизы, изначально воспринимает свой отъезд из дома как необходимую временную разлуку с отцом, духовная связь с которым не прерывалась никогда.

Роман Н. С. Лескова, опубликованный в 1864 году и вызвавший откровенное неприятие со стороны литературной критики, предвосхитил многие исторические коллизии второй половины XIX века. Негативные явления, ставшие следствием сознательного вторжения в естественный исторический ход, во многом повлияли и на человеческие

${ }^{5}$ Лесков Н. С. Собр. соч.: В 6 т. Т. 1. М., 1993. С. 637. 
судьбы. В этой внутриличностной борьбе огромную роль играет оппозиция - нигилизм как новомодное общественное явление и вековые родовые устои, основанные на необходимости принятия вечных законов бытия и подчинения им.

Образ Лизы Бахаревой, девушки из провинции, выпускницы института благородных девиц, стал ярким примером отпадения от отчего дома, самоотчуждения сознания героини, определившего драматизм ее дальнейшей жизни. Мотив блудной дочери, обозначившийся уже в начале романа на уровне сюжетного повествования, усложняется по мере движения событийной линии и расширения системы персонажей в ходе развития действия романа. Не случайно Лиза Бахарева возвращается домой вместе с Женни Гловацкой, бывшей курсанткой того же столичного института. Однако мотив блудной дочери по отношению к Женни не получает дальнейшего развития и не затрагивает ее внутреннего мира. Образ этой героини остается в рамках благополучного разрешения. Для Лизы же возвращение домой является лишь катализатором сложных внутриличностных процессов, следствием которых стал сознательный уход из дома и окончательный разрыв родовых уз.

Художественная реализация мотива блудной дочери в образе Лизы Бахаревой очень схожа с реализацией этого мотива в романе И. А. Гончарова «Обрыв» (вспомним образ Веры, такой же девушки из провинции, но, в отличие от своей литературной предшественницы, не покидавшей отчего дома и не подверженной автором испытанию на прочность ее связи с родовыми традициями). Однако это не является панацей от жизненной драмы самой героини, что так же, как и в случае с Лизой, обусловлено ее личностным сознанием и психологическими особенностями. Постоянная рефрлексия и сила духа Веры наделяют ее способностью противостоять нигилистическому натиску Марка Волохова, основной целью которого является полный разрыв родовых уз со стороны его избраннищы. В связи с самостоятельностью суждений Веры, почти абсолютной автономностью ее сознания героиня испытывает колоссальную ответственность и за поступки, которые она совершает. Вряд ли Веру можно назвать победительницей. Но становится очевидным, что в романе Гончарова в откровенном противостоянии нигилизма и родового начала последнее слово остается за вековой традицией. Симптоматичен и тот фракт, что Вера повторяет судьбу своей бабушки, Татьяны Марковны Бережковой, в свое время попавшей в подобную ситуацию и сумевшей сохранить самое ценное зерно своей души - родовую память. Именно бабушка оказалась спасительной силой и той связующей нитью, которая не позволила Вере утратить ощущение твердой почвы, а значит, и ясного будущего. 